\title{
Hambatan Komunikasi Antarbudaya Pekerja Asing yang Bekerja di Jakarta
}

\author{
Reza Kristiani, Lusia Savitri Setyo Utami \\ reza.915160179@stu.untar.ac.id,lusias@fikom.untar.ac.id
}

Fakultas Ilmu Komunikasi Universitas Tarumanagara

\begin{abstract}
The developments in Indonesia, especially in the capital city of Jakarta, have now become one of the livelihood fields that interest foreign citizens. However, due to differences in citizenship, language and culture, foreign workers who work in Jakarta experience obstacles in communication in Indonesia. In addition, the flow of globalization in metropolitan cities such as Jakarta is developing rapidly, resulting in the diminishing culture of the people residing in this city. However, it cannot be denied that there are still a number of phenomena caused by cultural differences between foreign workers and the people of Jakarta. These barriers make a noneffective communication of foreign workers. This study uses a descriptive qualitative research with the phenomenological method. The theoretical foundation used in this research is communication theory, intercultural communication and intercultural communication barriers. The results showed, of the six barriers to intercultural communication put forward by Devito, only four barriers were experienced by foreign workers who worked in Jakarta, there are stereotypes, misinterpretations of the meaning of verbal and nonverbal messages, violations of customs and culture and culture shock. Whereas prejudice and ethnocentrism do not become obstacles for foreign workers because foreign workers have a more open mind in a new environment they occupy.
\end{abstract}

Keywords: foreign worker, intercultural communication, intercultural communication barrier.

\begin{abstract}
Abstrak
Perkembangan yang terjadi di Indonesia, khususnya ibukota Jakarta saat ini menjadi salah satu lahan penghidupan yang diminati oleh para warga negara asing. Namun karena adanya perbedaan kewarganegaraan, bahasa, dan budaya, para pekerja asing yang bekerja di Jakarta mengalami hambatan dalam berkomunikasi di Indonesia. Di samping itu arus globalisasi di kota metropolitan seperti Jakarta berkembang dengan cepat, sehingga mengakibatkan kekentalan budaya masyarakat yang berada di kota ini menjadi semakin berkurang. Namun tak dapat dipungkiri bahwa masih terjadi beberapa fenomena yang diakibatkan oleh perbedaan budaya antara pekerja asing dan masyarakat Jakarta. Hambatan inilah yang membuat komunikasi para pekerja asing menjadi tidak efektif. Penelitian ini menggunakan pendekatan penelitian kualitatif deskriptif dengan metode fenomenologi. Adapun landasan teoritik yang digunakan dalam penelitian ini yaitu teori komunikasi, komunikasi antarbudaya dan hambatan komunikasi antarbudaya. Hasil penelitian menunjukan, dari enam hambatan komunikasi antarbudaya yang dikemukakan oleh Devito, hanya empat hambatan yang dialami oleh para pekerja asing yang bekerja di Jakarta, yakni stereotip, kesalahan pemaknaan arti pesan verbal dan nonverbal, terjadinya pelanggaran terhadap adat kebiasaan dan budaya serta gegar budaya. Sedangkan prasangka dan etnosentrisme tidak menjadi hambatan bagi para pekerja asing karena para pekerja asing memiliki pemikiran yang lebih terbuka dalam suatu lingkungan baru yang mereka tempati.
\end{abstract}

Kata Kunci: hambatan komunikasi antarbudaya, komunikasi antarbudaya, pekerja asing. 


\section{Pendahuluan}

Indonesia merupakan salah satu negara berkembang yang mengalami pertumbuhan baik di sektor ekonomi maupun sektor lainnya yang menarik minat warga negara asing untuk memilih Indonesia sebagai lahan penghidupannya. Hal tersebut merupakan salah satu alasan meningkatnya jumlah warga negara asing di Indonesia, khususnya Jakarta, ibukota Indonesia. Warga negara asing yang bekerja dan menetap di Indonesia, sering disebut sebagai pekerja asing. Menurut pernyataan Kementerian Ketenagakerjaan yang dikutip dari sebuah situs online, pekerja asing yang berada di Indonesia berjumlah 95.335. Berdasarkan jumlah tersebut, pekerja asing yang bekerja di Indonesia, terdiri dari tenaga asing profesional sebanyak 30.626, manajer sebanyak 21.237, konsultan dan direksi sebanyak 30.708. Mayoritas para pekerja asing ini bekerja dan menetap di Jakarta (Gus, 2019).

Di samping itu era globalisasi yang cepat berkembang di kota metropolitan ini membuat kepedulian warga Jakarta terhadap budaya semakin berkurang. Kementerian Pendidikan dan Kebudayaan mencatat terjadi penambahan jumlah cagar budaya di Jakarta. Tercatat ada empat cagar budaya yang baru ditetapkan oleh pemerintah sepanjang tahun 2017. Hal ini dilakukan sebagai upaya pemerintah meningkatkan kepedulian warga Jakarta akan budaya. Melihat hal tersebut, terkadang nilai, norma dan budaya dianggap tak menjadi halangan untuk berinteraksi dan berkomunikasi antar sesama warga Jakarta ataupun warga asing. Para pekerja yang bekerja di Indonesia juga tidak terlalu menghiraukan dengan siapa mereka bekerja dan bagaimana cara yang baik untuk berinteraksi, sehingga dapat menimbulkan kesalahpahaman karena terjadi hambatan komunikasi yang disebabkan oleh perbedaan budaya di antara mereka.

Keberadaan pekerja asing di Indonesia, tentunya mengharuskan mereka bukan hanya untuk bekerja saja, namun juga untuk membangun hubungan baik dengan lingkungannya. Maka dari itu pekerja asing juga harus bisa berkomunikasi dan beradaptasi dengan masyarakat Indonesia. Keahlian dalam berkomunikasi diperlukan untuk memenuhi kebutuhan dasar individu tersebut, seperti menghadapi lingkungannya terutama jika itu adalah lingkungan yang baru ia tempati (Utami, 2015). Namun hal tersebut tidak dapat dianggap mudah. Perbedaan cara berkomunikasi serta latar belakang budaya pekerja asing sangat mempengaruhi kemampuan berkomunikasi di masyarakat. Perbedaan ini merupakan salah satu ciri hambatan komunikasi yang bisa berujung pada komunikasi yang tidak efektif antara pekerja asing dengan masyarakat Jakarta. Dari latar belakang di atas, adapun tujuan dari penelitian ini adalah untuk mendeskripsikan hambatan komunikasi antarbudaya pekerja asing yang bekerja di Jakarta.

Landasan teoritik dalam penelitian ini adalah komunikasi, komunikasi antarbudaya dan hambatan komunikasi antarbudaya. Carl L. Hovland (2016) menyatakan upaya yang dilakukan dalam menyampaikan informasi, pembentukan pendapat dan sikap. Lalu mengenai komunikasi antarbudaya Samovar (2010) mengemukakan komunikasi antarbudaya terjadi, saat seseorang dengan latar belakang budayanya, menyampaikan pesan kepada orang lain dengan latar belakang budaya yang berbeda. Komunikasi antarbudaya melibatkan interaksi antara orang-orang yang mempunyai persepsi budaya dan sistem simbolnya cukup berbeda dalam komunikasi. 
DeVito (2011) menyatakan bahwa hambatan komunikasi sebagai segala sesuatu yang dapat mengubah pesan, berupa hal apapun yang menghalangi penerima menerima pesan. Kemampuan berkomunikasi ini bukan hanya semata mata bisa mengatasi perbedaan bahasa saja, namun juga latar belakang budayanya. Semakin besar perbedaan antar budaya, semakin sulit komunikasi dilakukan. Masalah dalam berkomunikasi yang dialami oleh pekerja asing sering muncul dalam bentuk kesalahpahaman terhadap persepsi-persepsi sosial yang disebabkan oleh perbedaanperbedaan kebudayaan yang mempengaruhi proses persepsi.

Hambatan komunikasi yang terjadi akibat perbedaan latar belakang budaya yaitu hambatan komunikasi antarbudaya. Hambatan komunikasi antarbudaya (Intercultural communication barrier) dapat berupa perbedaan perilaku, perbedaan bahasa, dan perbedaan lainnya yang menghambat dalam proses komunikasi yang berlangsung. Cara seorang individu dalam berkomunikasi sangat dipengaruhi oleh bahasa, budaya, aturan, dan norma masing-masing (Liliweri, 2011). Banyak faktor yang harus diperhatikan untuk membentuk komunikasi yang efektif, terutama dengan latar belakang budaya yang berbeda.

\section{Metode Penelitian}

Dalam penelitian ini, peneliti menggunakan pendekatan penelitian kualitatif, yang sering digunakan dalam memahami penelitian di bidang ilmu sosial. Moleong (2012) mengemukakan penelitian kualitatif adalah penelitian yang bertujuan untuk memahami fenomena yang dialami oleh subjek penelitian dengan cara dideskripsikan dengan kata-kata dan bahasa, pada suatu topik alamiah dan dengan menggunakan berbagai metode ilmiah.

Peneliti menggunakan metode fenomenologi untuk mendapatkan data dan informasi yang dibutuhkan terkait dengan hambatan komunikasi antarbudaya yang dialami oleh pekerja asing yang bekerja di Jakarta. Fenomenologi dipahami sebagai pengalaman pribadi atau studi tentang kesadaran dari pikiran pokok seseorang (Moleong, 2012).

Peneliti memilih tiga informan dengan dengan kewarganegaraan yang berbeda dan memiliki kriteria, bukan warga negara Indonesia, bekerja dan menetap di Jakarta, telah menetap di Jakarta selama minimal 6 bulan dan tidak fasih dalam berbahasa Indonesia. Dalam teknik mengumpulkan data, peneliti menggunakan empat cara yaitu observasi partisipatif, wawancara mendalam, dokumentasi dan studi kepustakaan. Teknik keabsahan data yang digunakan dalam penelitian ini yaitu triangulasi sumber. Menurut Moleong (2010) triangulasi sumber digunakan untuk menguji kredibilitas data yang dilakukan dengan cara mengecek data yang telah diperoleh melalui beberapa sumber. Hasil data yang diperoleh dari berbagai sumber dianalisis dan dideskripsikan, dikategorikan, mana pandangan yang sama dan yang berbeda.

\section{Hasil Penemuan dan Diskusi}

Hambatan komunikasi antarbudaya yang dialami oleh ketiga informan disesuaikan dengan teori yang dipaparkan oleh Devito (2011) terdapat enam hambatan komunikasi antarbudaya yang dapat dirasakan seseorang ketika masuk dalam lingkungan yang baru. Namun melalui wawancara yang dilakukan, peneliti hanya mendapatkan empat hambatan komunikasi antarbudaya yang dirasakan oleh para informan. 
Yang pertama adalah stereotip. Stereotip dari masyarakat Jakarta yang Mariana terima yaitu orang asing memiliki banyak uang. Mariana diberikan harga yang lebih tinggi dari pengunjung lainnya saat hendak membeli sebuah barang di tempat wisata. Dari hasil penelitian menyatakan bahwa, nilai tukar rupiah yang kecil berpengaruh pada pola pikir masyarakat khususnya yang menengah ke bawah (yang tidak mengetahui mengenai nilai tukar mata uang), seperti para pedagang kaki lima, yang menganggap bahwa orang asing selalu memiliki banyak uang. Perlakuan ini biasa dirasakan oleh Mariana di tempat-tempat umum lainnya di Jakarta. Hal ini tentu diakibatkan oleh stereotip yang diberikan oleh warga Jakarta terhadap warga asing yaitu memiliki banyak uang. Di sisi lain James tidak terlalu merasakan adanya stereotip pada mula-mula ia tinggal di Jakarta. Namun ia juga setuju ada perlakuan yang sama seperti yang pernah Mariana alami saat James berada di sebuah tempat umum.

Park Han Seok yang berasal dari Korea pun menerima penstereotipan dari masyarakat Jakarta. Stereotip yang diterima oleh Park Han Seok merupakan bentuk stereotip yang dipengaruhi oleh stereotip masyarakat Jakarta terhadap orang Cina yang juga menetap di Jakarta. Warga Jakarta menstereotipkan orang Cina sebagai orang yang selalu mencari untung dan pelit. Karena memiliki perawakan yang mirip dengan ras Cina, Park Han Seok juga dilayani paling terakhir seperti orang Cina saat berada di sebuah tempat makan. Pengertian stereotip menurut Samovar (2010) yaitu bentuk dari pengelompokan yang mengarahkan sikap individu tersebut dalam menghadapi orang-orang tertentu. Dari pernyataan diatas, dapat dikatakan bahwa stereotip selalu diterima oleh para pekerja asing yang datang dan menetap di Jakarta. Stereotip yang terjadi mulai dari pandangan yang mengelompokan dan membedakan seseorang, berujung pada perlakuan yang berbeda juga, seperti yang dialami oleh para informan.

Yang kedua yaitu kesalahan dalam pemaknaan arti pesan verbal maupun nonverbal. Menurut hasil wawancara dari para informan, bahasa Indonesia adalah bahasa yang tidak mudah untuk dipelajari, maka dari itu hambatan terbesar dari komunikasi antarbudaya dengan masyarakat Jakarta adalah bahasa. Ketiga informan mengaku kesulitan untuk berkomunikasi dengan verbal baik lisan maupun tulisan dalam bahasa Indonesia. Meskipun teknologi yang ada sangat membantu untuk menerjemahkan bahasa asing ke bahasa Indonesia, namun para informan merasakan adanya perbedaan arti yang dipengaruhi oleh latar belakang budaya masing-masing orang yang menjadi lawan komunikasinya. Hasil wawancara menunjukan kesesuaian dengan apa yang dituliskan oleh Devito (2011) bahwa, meski kata atau bahasa yang digunakan sama, makna konotatif dari kata atau kalimat tersebut akan sangat berbeda bergantung pada definisi budaya pendengarnya.

Selain hasil wawancara, peneliti juga mengumpulkan sejumlah data mengenai kesalahan dalam pemaknaan pesan verbal dalam obrolan online antara peneliti dan informan. Hal ini berkaitan dengan budaya konteks tinggi dan budaya konteks rendah, yang dapat menghambat komunikasi. Terjadi miskomunikasi antara Mariana yang berasal dari Brazil memiliki budaya konteks rendah, dengan peneliti yang berasal dari Indonesia yang memiliki budaya konteks tinggi. Menurut Edward T. Hall (2009) penganut budaya konteks rendah adalah orang yang berpikir logis, individual dan berorientasi pada tindakan, menghargai logika, fakta dan kejujuran. Budaya konteks rendah selalu menggunakan kata-kata yang tepat yang langsung dapat dipahami secara harfiah. Sedangkan penganut budaya konteks tinggi lebih bersifat relatif, kolektif, intuitif dan menekankan hubungan interpersonal. Secara komunikasi, budaya konteks 
Reza Kristiani, Lusia Savitri Setyo Utami: Hambatan Komunikasi Antarbudaya Pekerja Asing yang Bekerja di Jakarta

tinggi lebih bertele-tele dan formal, menggunakan kata-kata yang dirangkai terlebih dahulu.

Mariana dengan budaya konteks rendah, secara langsung mengutarakan keinginannya untuk bertemu dengan peneliti secara langsung di waktu yang sama saat melakukan obrolan online, namun di sisi lain peneliti menangkap arti yang berbeda. Terjadi miskomunikasi saat peneliti mengutarakan akan menjelaskan topik wawancara. Peneliti mengira penjelasan topik awal dapat dilakukan melalui obrolan online terlebih dahulu, setelah itu melakukan janji untuk bertemu. Selain itu pembuktian perbedaan budaya konteks tinggi dan budaya konteks rendah yang bisa menjadi faktor penghambat komunikasi yaitu dari panjangnya balasan obrolan online yang diberikan. Mariana cenderung memberikan jawaban yang singkat dan padat, langsung pada inti percakapan, sedangkan peneliti memberikan jawaban yang lebih panjang dengan maksud untuk memberikan rasa nyaman, ramah dan juga sopan. Dalam hal ini peneliti juga berasumsi mungkin saja jawaban yang pendek ini dikarenakan informan merasa terganggu ataupun tidak senang. Namun akhirnya peneliti menyadari bahwa adanya perbedaan budaya konteks rendah dan konteks tinggi yang juga bisa mengakibatkan hambatan dalam berkomunikasi.

Yang ketiga yaitu gegar budaya. Gegar budaya merupakan hambatan yang umumnya terjadi ketika seseorang memasuki lingkungan yang baru. Menurut Devito (2011), gegar budaya mengarah pada reaksi psikologis yang dialami seseorang karena berada di dalam suatu budaya yang sangat berbeda dari budayanya sendiri. Gegar budaya yang dialami oleh James 6 tahun lalu, saat pertama kali menetap di Jakarta adalah ketika ia mencoba untuk berkomunikasi dengan orang-orang di Indonesia. Sebelum berangkat ke Jakarta, James mempelajari bahasa Indonesia selama bangku sekolahnya. Selain itu James juga mengaku telah mempelajari kebudayaan Indonesia saat di awal perguruan tinggi. Awalnya James merasa memiliki bekal yang cukup baik untuk bisa menetap di Jakarta, namun hal tersebut menjadi sebuah hambatan bagi James saat beradaptasi dengan warga Jakarta. Kemampuannya dalam berbahasa Indonesia, dianggap aneh dan lucu oleh orang-orang disekitarnya karena James menggunakan bahasa Indonesia dengan bentuk yang formal, sama seperti yang ia pelajari saat di Australia. Ketika ia mempraktekan kemampuan bahasa Indonesianya untuk berkomunikasi dengan orang di Jakarta, James terkaget karena bahasa yang ia pelajari jauh berbeda dengan apa yang digunakan oleh orang Jakarta.

James mendapatkan perlakuan yang kurang menyenangkan dari orang-orang di sekitarnya terkait dengan bahasa Indonesia formal yang ia gunakan. Akibatnya James lebih sering menggunakan bahasa Inggris sebagai bentuk pertahanannya. James juga menghindari untuk melakukan komunikasi dengan bahasa Indonesia. James juga mengaku tidak merasa nyaman untuk berkomunikasi secara langsung dengan orang Jakarta karena hal tersebut.

Reaksi yang dialami oleh James, sesuai dengan apa yang dituliskan oleh Samovar Porter \& McDaniel (2014) mengenai reaksi yang biasanya terjadi, dan sering dialami oleh individu saat mengalami gegar budaya, salah satunya juga dialami oleh James yaitu menarik diri. James memutuskan untuk tidak berbicara dengan bahasa Indonesia dan menghindari kontak langsung dengan orang Indonesia. Samovar juga menuliskan bahwa individu yang mengalami gegar budaya tak hanya akan berhenti merespon dan bereaksi saja, namun mereka akan mengalami beberapa kondisi yang mengharuskan mereka untuk beradaptasi dengan budaya yang baru, agar bisa bertahan. 
Yang keempat adalah pelanggaran adat kebiasaan budaya. Devito (2011) menyebutkan dalam bukunya bahwa setiap budaya mempunyai aturan dalam berkomunikasi masing-masing. Aturan ini memastikan mana yang boleh dan mana yang tidak boleh dilakukan. Baik di Indonesia maupun negara lain memiliki aturan dan kebiasaannya masing-masing, dan apabila dilanggar pastinya akan ada sanksi ataupun perlakuan yang berbeda bagi para pelanggar, seperti yang terjadi pada Mariana. Budaya barat dimana tempat Mariana berasal terbiasa untuk melakukan kontak fisik intim dengan pasangannya di tempat umum, seperti yang Mariana lakukan yaitu berciuman di sebuah tempat perbelanjaan. Namun pada saat itu, Mariana merasa mendapat perhatian yang berlebih dari orang-orang yang berada di dekatnya, yang membuat dirinya dan suaminya merasa tidak nyaman. Orang-orang melihat Mariana dan pasangannya dengan tatapan tajam setelah berciuman.

Masyarakat Jakarta yang menjunjung tinggi kesopanan dan beretika di lingkungan tempat tinggalnya tidak terbiasa dengan kebiasaan orang asing yang lebih bebas dalam berlaku di masyarakat. Sehingga hal yang dilakukan Mariana tentu akan menjadi sorotan mata, karena tidak biasa dilakukan oleh orang Indonesia. Budaya Indonesia yang jauh berbeda dengan budaya asing terutama dari bagian negara barat, membawa hambatan yang cukup mengganggu dalam bersosialisasi dengan lingkungannya.

Setelah mendapatkan perlakuan tersebut, Mariana mengaku mulai mempelajari hal-hal yang sopan dilakukan di tempat umum dan yang tidak, karena bagaimanapun ia berada dalam lingkungan dan kawasan yang berbeda dari tempatnya berasal. Meskipun berada di kota metropolitan, Mariana menyadari dan menghargai nilai dan norma yang ada di Indonesia yang masih berlaku dan baik adanya untuk menjaga keharmonisan yang ada di tengah-tengah masyarakat Jakarta.

Berdasarkan hasil wawancara etnosentrisme dan prasangka tidak menjadi hambatan para pekerja asing dalam berkomunikasi dengan warga Jakarta. Liliweri (2009) menyatakan etnosentrisme merupakan sikap seseorang yang menganggap kelompoknya lebih superior dibandingkan dengan kelompok lain. Berdasarkan wawancara yang dilakukan oleh peneliti terhadap ketiga informan selama menetap di Indonesia belum pernah mengalami perlakuan yang mengarah kepada etnosentrisme baik dari masyarakat Indonesia maupun kesadaran dari diri mereka sendiri. Ketiga informan mengaku bahwa masyarakat Jakarta, sangatlah ramah, suka menolong dan selalu tersenyum.

Sedangkan mempersepsikan sikap seseorang secara negatif dapat disebut prasangka. Menurut Samovar, Porter dan McDaniel (2014) prasangka merupakan menyamakan sesuatu dan bersifat kaku serta menyakitkan mengenai sekelompok orang. Prasangka merupakan hasil dari sikap yang selalu menilai perbedaan budaya lain dengan budaya sendiri. Dari hasil wawancara dengan para informan, mereka mengaku sangat jarang membandingkan nilai, norma, adat dan budaya-budaya yang ada di Indonesia sehingga berujung menjadi sebuah prasangka yang negatif. Sebaliknya para informan menemukan bahwa semua hal mengenai nilai, norma, adat dan budaya-budaya yang ada di Indonesia, memiliki keunikan tersendiri dan juga memiliki daya tarik yang membuat para warga negara asing terkesima dan ingin mengetahui lebih jauh mengenai Indonesia. 
Reza Kristiani, Lusia Savitri Setyo Utami: Hambatan Komunikasi Antarbudaya Pekerja Asing yang Bekerja di Jakarta

\section{Simpulan}

Berdasarkan hasil analisis dan wawancara yang dilakukan oleh peneliti terhadap ketiga informan mengenai hambatan komunikasi antarbudaya yang dialami oleh pekerja asing yang bekerja di Jakarta, maka penulis menemukan bahwa komunikasi antarbudaya dipraktekan antara individu atau kelompok yang memiliki latar belakang budaya yang berbeda. Pekerja asing yang datang ke Jakarta pasti melakukan komunikasi antarbudaya dengan masyarakat Jakarta. Namun selama proses komunikasi antarbudaya berlangsung terdapat hambatan yang diakibatkan oleh perbedaan budaya baik dari pekerja asing ataupun masyarakat Jakarta.

Hambatan komunikasi antarbudaya yang dialami pekerja asing ini salah satunya juga diakibatkan oleh kurangnya pemahaman mengenai komunikasi antarbudaya. Pekerja asing yang hendak dipekerjakan di negara lain, lebih baik sudah memiliki pengetahuan mengenai negara yang akan dituju, sehingga dapat mengurangi hambatan-hambatan komunikasi yang bisa saja terjadi.

\section{Ucapan Terima Kasih}

Penulis mengucapkan rasa terima kasih kepada semua pihak yang memberikan bantuan baik mental maupun materi selama penelitian ini berlangsung sampai dengan selesai. Peneliti juga mengucapkan terima kasih kepada semua pihak yang telah membaca penelitian ini.

\section{Daftar Pustaka}

Bangun, Wilson. (2012). Manajemen Sumber Daya Manusia. Jakarta: Penerbit Erlangga

Budyatna, Muhammad. (2012) Komunikasi Bisnis Silang Budaya. Edisi pertama. Jakarta: Kencana Prenada Media Group.

Cangara, Hafied (2016) Pengantar Ilmu Komunikasi Raja Grafindo Persada Jakarta

Devito, Joseph. (2011). Komunikasi Antarmanusia. Tangerang: Karisma Publishing Group

Effendy, Onong Uchjana. (2016) Ilmu Komunikasi : Teori dan Praktek. Bandung : PT. Remaja Rosdakarya.

Fajar, Marhaeni. (2009). Ilmu Komunikasi Teori \& Praktik Edisi Pertama. Yogyakarta: Graha Ilmu.

Kusherdyana. (2011). Pemahaman Lintas Budaya. Bandung: Alfabeta

Liliweri, Alo. (2011). Komunikasi Serba Ada Serba Makna. Jakarta: Kencana Preda Media Group

Sukmadinata, Nana Syaodih. (2010). Metodologi Penelitian Pendidikan. Bandung: Remaja Rosdakarya

Suryanto.(2015). Pengantar Ilmu Komunikasi. Bandung: CV Pustaka Setia

Samovar, L. A., Porter, R. E., \& Daniel, E. R. (2014). Komunikasi Lintas Budaya. Jakarta: Salemba Humanika

Utami, Lusia Savitri S. (2018). Teori-Teori Adaptasi Antar Budaya. Jurnal Komunikasi. (n.d.). Retrieved December 19, 2019, from https://journal.untar.ac.id/index.php/komunikasi/article/view/17/38 
Tenaga Kerja Asing Masuk RI Melesat 38\% Terbanyak Asal China. (2019, September 09). Retrieved September 12, 2019, from Detik: https://finance.detik.com/berita-ekonomi-bisnis/d-4699585/tenaga-kerjaasing-masuk-ri-melesat-38-terbanyak-asal-china

Statistik Kebudayaan dan Bahasa 2018. (2019, Januari 01). Retrieved January 14, 2020, from

Kemdikbud.go.id: http://publikasi.data.kemdikbud.go.id/uploadDir/isi_BE2D808C-AC9F-4962963A-12FCE0EA163E_.pdf 